\title{
Analysis of Product Innovation of Cibuntu Tofu at Cibuntu Tofu Center Bandung
}

\author{
Trustorini Handayani \\ Department of Management, Faculty of \\ Economics and Business \\ Universitas Komputer Indonesia \\ Bandung, Indonesia \\ trustorini.handayani@email.unikom.ac.id
}

\begin{abstract}
Cibuntu Tofu Center is a tofu industry that has operated in Bandung for some time and still exists today. There are many new competitors outside Cibuntu Tofu Center emerging by offering a different kind of innovations, while only a few tofu producers at Cibuntu Tofu Center doing the product innovation. The purpose of this research is to observe product innovation conducted in Cibuntu Tofu Center. The method used in this research was a descriptive and quantitative method. Quantitative analysis was used by compiling the distribution frequency table to determine the level of the research variables into the category: very good, good, quite good, not good, not very good. The sampling technique used in this research was saturated sampling in which 20 respondents of tofu producers at Cibuntu Tofu Center Bandung became the sample. The results obtained the total score of Product innovation of $65.25 \%$, which was in the "quite good" category. The highest score $(75 \%$ - in the "good" category) was an indicator of adding features or creating a new model of the product. Besides, the indicator of changing the producting requirement scored $60 \%$ including to the "quite good" category. Lastly, the lowest percentage $(55,5 \%$ - in the "quite good" category) was an indicator of changing the product composition.
\end{abstract}

Keywords--Product Innovation, Cibuntu Tofu

\section{INTRODUCTION}

Bandung as the city of Paris Van Java has a very diverse potential. Besides the city of Fashion, Bandung is also popular as a culinary city. Various cuisines offered in this city to the people, one of them is tofu. Tofu is a traditional food that almost everyone likes. The characteristics of traditional food according to Sosrodiningrat [1] are: "1) Food recipes are passed down from generation to generation. 2) The use of certain traditional tools in the cooking Product (for example the dishes are cooked using brick stoves)".

On the web page of sentraindustribandung.com it is mentioned "there are approximately 408 tofu producers in Cibuntu. The annual Production capacity is 2,161 million pieces of tofu. The investment value reaches 13,472 billion IDR. This industry can absorb as many as 1,518 workers. Cibuntu tofu still becomes a favorite even though many tofu Products have emerged rapidly. The good characteristics of Cibuntu tofu are odorless and natural tasteful. The taste and quality are still maintained until today which makes this tofu still popular and becomes a favorite. Cibuntu tofu is produced manually through strict supervision. The water used comes from good quality artesian water. This tofu uses natural turmeric preservatives."[2]

Some research on tofu has been conducted. Rusdiana [3] explains "the comparison of mixed soybeans (local and imported) affects the quality of tofu produced". Satrio, Dwi also explained, "the amount of Cibuntu tofu Production during the research showed a decrease due to the defective raw material or soybeans ". [4]

From the previous research, it is known that a research on Product innovation of Cibuntu tofu has not been done. Thus, through this research, the writer wants to highlight Cibuntu tofu industry in terms of its Product innovation. "Product innovation describes changes in the way an organization produces end Products and services of a company" [5]. This research was conducted because Cibuntu tofu is a tofu industry that has operated and existed for a long time in Bandung even though there are many new competitors which are starting to emerge by offering tofu with a variety of different shapes, colors, flavors and technologies. To support the discussion of Product innovation of Cibuntu tofu, the writer used descriptive analysis method in order to find out the innovations that are carried out by the tofu producers at Cibuntu Tofu Centre based on the following indicators:

"Adding new features/models, changing the Producting requirements, changing the ingredients/ Product elements," Improvement of new Products is the introduction of new versions or Product models that have been developed to replace old ones. New Product improvements can be done by:

1. Adding new features/model,

2. Changing the Producting requirement,

3. Changing the ingredients/elements of the Product."[6]

Consequently, the research results can be useful for the knowledge development and for the producers of Cibuntu tofu in terms of its Product innovation."Product innovation has a positive effect on the market performance"[7]

\section{METHOD}

The method used in this research was descriptive and quantitative method through explanatory survey research. This method was used because the writer wants to describe the Product innovation run at Cibuntu Tofu Centre Bandung. "Quantitative analysis is used to arrange the distribution frequency table to determine the level of value (score) of the research variable, i.e. very good, good, quite good, not good, 
not very good. Furthermore, the rank of each research variable can be evaluated from the comparison between the actual score and the ideal score. The actual score was obtained through the calculation of all respondents' opinions according to the classification of given weights $(1,2,3,4$, and 5$)$. While the ideal score was obtained through the acquisition of the highest value prediction multiplied by the number of questionnaires multiplied by the number of respondents." [8]

In this research, there was only one variable that was examined, i.e. the Product innovation variables. The Product Variabel have 3 indicator that was 1. Adding new featurs/model, 2. Changing the Producting requirement, 3. Changing the ingredients/elements of Product. There were two types of data used by researchers; Primary data and secondary data. "Primary data was obtained directly from the object under study such as the respondents and data from direct interviews with tofu producers. While Secondary data is a complement to the primary data. It was obtained by reading, studying, and understanding literature and books."[8]. The population of this research was 20 tofu producers at Cibuntu Tofu Centre, Babakan Ciparay Gang Aki Padma, and Bandung. The sampling technique used was saturated sampling so that the number of sample in this study was 20 respondents from the total population of 20 Cibuntu tofu producers.

\section{RESULTS}

\section{A.The Characteristic of the Respondent}

The characteristic of the respondent is grouped into four categories; they are based on business duration, education, business income, and age. The first characteristic is based on the business duration. Most respondents have run their businesses for 5-10 years because Cibuntu Tofu Centre is a business center that has been operated for a long time. The second characteristic is based on the respondents' last education. In general, the respondents' last education is junior high school. Education is not considered a major factor in running the business so that they have less knowledge and skills in managing and organizing their businesses. Hasibuan [9] explains "education is an indicator that reflects a person's ability to complete a job". The third characteristic of the respondents is based on business income. The majority of respondents earn less than 500,000 IDR and 500,000 IDR $1,000,000$ IDR. This is because the business of Cibuntu tofu is a food business which sells the Products at affordable price. The last characteristic of the respondents is based on age. Most respondents' age ranges from 26 to 35 years old. At the age of 26-25 years, a person usually has sufficient experience and knowledge that can be used in starting a business or starting as a worker in a company. Besides having good experience and knowledge a person of 26-35 years old usually has more stable emotions.

\section{B.Descriptive analysis of the Product innovation}

The results of descriptive analysis of tofu Product innovation at Cibuntu Tofu Center showed that indicator of adding new features or models obtained $76 \%$ of the categories. This indicated that tofu producers add the characteristics or create a new model by making tofu in a standard size and smaller size. The indicator of changing the production requirements obtained $60 \%$ which indicated that there was a little change in the Product of making tofu. The indicator of changing the ingredients/elements of the Product was 55.75\% which indicated that the tofu producers did not change the ingredients/element of the Products, for example, adding or reducing raw materials in the making of tofu. The total percentage of the Product innovation variables was $65.25 \%$ which indicated that the Product innovation in making tofu was in the "quite good" category. In the other words, the tofu producers at Cibuntu Tofu Centre, Babakan Ciparay Gang Aki

T Padma, had carried out the Product innovation quite well, this can be seen in the continuum line concerning the Product innovation variable in Fig 1 below.

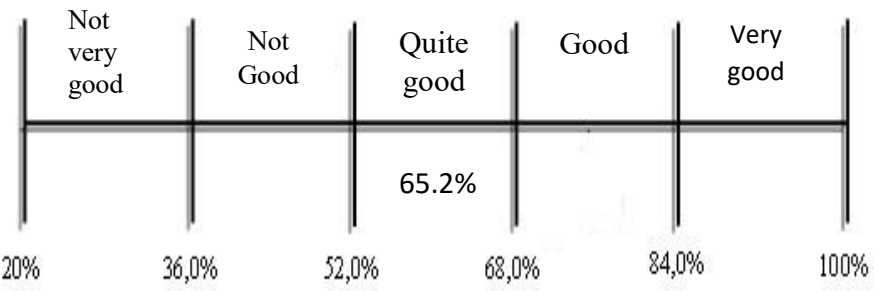

\section{DISCUSSION}

The total score of the innovation Product variable was $65.25 \%$ which showed that the innovation Product was in the "quite good" category. The highest percentage was $75 \%$ which indicated that the innovation Product was in the "good" category, i.e. adding new features/model of the Product. Compared to other indicators, making Cibuntu tofu in two different sizes (big and small size) and changing producing requirements scored $60 \%$ which was in the "quite good" category. The respondents will replace the tofu making machine when it is broken but they still use the same technology. In the other words, they still use the same machine and technology. The lowest score was $55.7 \%$ which was also in the "quite good" category, i.e. changing the ingredients/elements of the Product. the amount of Cibuntu tofu Production during the research showed a decrease due to the defective raw material or soybeans ".[4] According to the interview, the respondents said that they do not change the ingredients or raw materials with the consideration that the changes in ingredients and raw materials will affect the character and the taste of Cibuntu tofu which has been popular with its natural savory and preservative free."the decision to adopt a new product dependent on the characerst

Ittict of the family owning company, Risk-avoiding behaviour emerges when the inherent risk of the new product is higher than the threshold wich facilities the maintanance of company control"[10].Hartini explain "The Small Business have a product innovation and process innovation still very low".[5]

\section{CONCLUSION}

Based on the discussion, it is concluded that the innovation made by Cibuntu tofu producers was in the "quite good" category, which explained by the indicator of adding new features/model (in the "good" category), changing the producing requirement (in the "quite good" category), and changing the ingredients/elements of the Product (in the "quite good" category)."Product innovation plays a critical role in 
the development of new products, process efficiency, and sustained competitive advantage in terms of extending market share"'[11,12,13].

\section{ACKNOWLEDGMENT}

My gratitude goes to the tofu producers at Cibuntu Tofu Centre, the honorable Rector of Unikom, DR. H., Eddy Soeryanto Soegoto; Dean of the Faculty of Economics and Business, Prof.DR.Hj. Dwi Kartini, Spec. Lic;; as well as colleagues in the Management Study Program the Faculty of Economics, Universitas Komputer Indonesia, Bandung.

\section{REFERENCES}

[1] Maulida Ajeng Priyatnomo, Wahyu Khasanah, Moh Salimi, "Jajanan Tradisional Sebagai Bahan Ajar Pembelajaran IPS Untuk SEKOLAH DASAR" INOVASI PENDIDIKAN Bunga Rampai Kajian Pendidikan Karakter, Literasi, dan Kompetensi Pendidik dalam Menghadapi Abad $21 \quad 340 \quad$ Universitas $\quad$ Sebelas Maret,jurnal.fkip.uns.ac.id/index.php/snip/article/viewFile/11186/7972

[2] Serba Bandung, "Tahu Cibuntu Memproduksi Tahu Putih dan Kuning" Published 03/02/2015 · Updated 24/05/2016

[3] Rusdiana, "Perbandingan kedelai campuran (lokal dan impor) berpengaruh terhadap kualitas tahu yang dihasilkan" repository.unpas.ac.id, 2012

[4] Satrio, dwi, "Analisis Pengendalian Kualitas Produk Tahu Cibuntu Menggunakan Metode Statistical Quality Control Untuk Mengurangi Produk Cacat (Kasus Pada Home Industry Sutera H.Galih)" http://karyailmiah.unisba.ac.id/index.php/manajemen/article/view/526 5. 2016

[5] Sri Hartini, "Peran Inovasi: Pengembangan Kualitas Produk dan Kinerja Bisnis". Fakultas Ekonomi danBisnis, Universitas Airlangga Jl. Airlangga 4-6, Surabaya 60286 Email: hartini_unair@yahoo.com

[6] Agus Rahayu, Gita Anggarini. "Pengaruh Inovasi Produk Terhadap Keputusan Pembelian Produk Audio SONY (Survei pada Konsumen di Toko Aneka Irama Jalan ABC Bandung)" e-journal.upi.edu,strategic Vol 8 no.16, September 2009 Pendekatan Kuantitatif, kualitatif, dan R\&D”. Bandung: Alfabeta. 2010

[7] R.F. Hurley, G.Hult, "Innovation, market orientation, and Organizational Learning. An Integration and Empirical Examination, Journal of Marketing 62(3)(1998) 42-54

[8] Sugiyono. 2010." Metode Penelitian Pendekatan Kuantitatif, kualitatif, dan R\&D”. Bandung: Alfabeta. 2010

[9] Malayu Hasibun,'Manajemen Sumber Daya Manusia, Edisi Revisi”. Bumi Aksara.2005

[10] Marco Cuccuelli,Isabelle le breton Miller,Danny Miller,'Product Innovation, Firm renewal and family governance" ,Journal of Family Business Strategy.2016.Elsevier Ltd,Allright reserved.

[11] Hasan Aksoy, "How do innovation Culture, marketing innovation culture, marketing, innovation and product innovation affect the market performance of small and medium-sized enterprises (SMEs) Technology in Society (2017), doi: 10.1016/j.techsoc.2017.08.005.

[12] S.Brown, K.Eisenhardt, Product development past research, present finding, and future directions, Acad Management Rev.: 20(2)(1995) 343-378

[13]S.Salunken,J.Weerawardenab,J.R.Mc-Coll Kennedy,”Competing Throught service innovation the role of bricolage and entreprenuership in project-oriented firm, Journal of Business Research 66 (8)(2013) 1085-1097 